\author{
ÁGNES PÁL, FERENC GYőRI \\ University of Szeged, Szeged, Hungary
}

\title{
Contemporary Changes in the Role and Spatial Structure of Industrial Production in Hungary
}

\begin{abstract}
The aim of our paper is to offer a brief survey of the stages of development of industrial production in Hungary and the transfomation that followed the changing of Hungary's political system, as well as the main trends in the contemporary process of re-industrialization. Hungarian industry has long traditions; as early as the beginning of the 20th century, in certain branches, it was among the leading countries in the world. After the fall of the centrally planned economy of the communist system and following the crisis treatment policies of the post-communist years, Hungarian industry, today, has to survive in an open economy. The process of re-industrializaton in Hungary is, basically, an integral part of global industrial change while, at the same time, it is largely dependent on local industrial developments. The volume indices, the value of industrial investments and the number of employees in industry, are all indicators of a positive change. The processing industry represents a considerable proportion of industrial production in Hungary and, in addition, vehicle manufacturing is the most dynamically developing segment. At the same time, industry in Hungary can still be characterized by a dual structure; more than two thirds of its production value us produced by large companies. Small- and medium-sized companies have the possibility of being integrated into the production structure as suppliers. Some of Hungary's traditional industrial branches have deteriorated, while other segments have been able to change their structure and become dynamic again. The main focus of industrial production - due to capital investments by foreigners - has shifted towards the west, and the largest portion of its production value now comes from Hungary's western and central Transdanubian regions. The process of re-industralization is beneficial for those regions in which there is an adequate and ready supply of human resources.
\end{abstract}

Keywords: Hungarian industry; industrial development; industrial parks; industrial production; spatial structure; territorial structural changes

Received: 22 February 2016

Accepted: 20 July 2016

\section{Suggested citation}

Pál, Á., \& Győri, F. (2016). Contemporary Changes in the Role and Spatial Structure of Industrial Production in Hungary. Prace Komisji Geografii Przemysłu Polskiego Towarzystwa Geograficznego [Studies of the Industrial Geography Commission of the Polish Geographical Society], 30(3), 127-146.

\section{INTRODUCTION}

Central- and Eastern-European countries introduced major changes in the structure of their economies after changes in their political sytems occurred. Due to these changes, the economic structure in these countries does not show significant differences 
when compared to the EU average. At the same time, in the development of contemporary industry, there are trends which differ from the EU average: while the average rate of industrial production is falling in the EU 28 countries, similar indicators for the Central- and Eastern-European region are improving. As early as 2013, Hungary was one of the leading countries in Europe - with an industrial contribution of $26 \%$ to the national Gross Value Added (a figure that exceeded the EU average by 7\% (Központi Statisztikai Hivatal, 2014). With this figure, Hungary occupied 7th place in the industrial growth ranking list.

Industrial expansion is reflected in economic news and analyses which frequently focus on job-creating and capacity-building investments. It is a fact that not only the European, but companies from overseas and from the Far West frequently express their satisfaction with the Hungarian production and investment background. Thus, re-industrialization is coming into being, the local aspects and the basic content of which are mostly determined by global economic changes, as well as by international developmental trends, but which are, to some extent, also characterized by local economic specificities.

The dynamism of contemporary industrial growth does not mean the strengthening of Hungary's previous, now deteriorating, socialist industry. Re-industrialization is a very complex process, which can be characterized primarily by the emergence of production of information and communication technology (ICT) devices, as well as by expansion of high-tech industrial branches with larger Gross Value Added (GVA) figures (including manufacturing of ICT devices, vehicles and medicine) and the decline of traditional industrial branches (e.g. light industries built on mass production or the iron and steel industries). These features mean that the process of re-industrialization involves the emergence of new, state-of-the-art industrial branches, new activities and products in the country's economy, and, at the same time, a transformation in the structure of industry (Barta, Czirfusz, Kukely, 2008).

The aim of our paper is to offer a brief survey of the stages of industrial production in Hungary, the transfomation that followed the change in Hungary's political system, as well as the main trends in contemporary re-industrialization processes.

\section{ONE AND A HALF CENTURY OF HUNGARIAN INDUSTRIAL DEVELOPMENT}

It was during the period of the Austro-Hungarian Monarchy, after the Austro-Hungarian Compromise of 1867, that Hungarian industry thrived and this unbroken development lasted until the First World War. This was the same period during which - owing to the foundation of the Academy of Selmecbánya (1735) and the transformation of the Vocational Academy of Buda into a University of Engineering in 1872 - the number of well-trained industrial specialists significantly increased (Győri, 2011) and the most famous large Hungarian industrial companies were established. In addition, their typical products were sought-after internationally. Examples include products of flour milling, distilling, sugar manufacturing and canning, and meat industries. The fact that the Hungarian food industry manufactured for international markets, together with railway construction works of the same period in the Carpathian Basin, gave impetus to the development of mining, metallurgy and the machine building industries. The 
development of the latter speeded up around the turn of the 19th and 20th centuries in those industrial branches which boasted the top innovations of that age. Examples include the manufacture of electrical machinery, ships and machinery for the milling industry and for the manufacture of rolling stock (Bora, 1986). At the beginning of the 20 th century, the achievements of Hungarian engineers and innovators were already well-known internationally.

Owing to the Peace Treaty of Trianon (1920), which changed Hungary's borders and caused major territorial loss to the country, the country's natural spatial relationships in every area of economy and transport became curtailed and, as a result, economic development slowed. Hungary lost two thirds of its former territory; consequently, it had to make do with less than half of its former industrial plants and only a fragment of its former forests and ore-mines. The partitioning of the country's formerly-unified economic area was disadvantageous, not only for Hungary, but also for the regional development of other countries in the Carpathian Basin (Gulyás, 2010). These traumatic effects were somewhat lessened by the working foreign capital that flowed into Hungarian industry during the period between the two world wars. First, it was the textile and clothing industries that became the prime movers of development, but soon the steel, metallurgy, machine-building, electro-technology and chemical industries started to catch up. Large companies attributed innovation and technological development with increasing importance and, due to this feature, the products of Hungarian industry became internationally competitive (Hajdú, 1996). During this period more than half of Hungary's industrial workers were employed in heavy industry, one third in light industry and one tenth in the country's food industry.

During the Second World War, two fifths of Hungary's national assets, and the majority of the country's industrial plants, were destroyed. The destruction of the means of production was made worse by the fact that first it was the German, then later the Soviet troops that systematically robbed the country of its remaining industrial machinery and equipment (Probáld, 2011). Hungary was invaded by the Soviet army and, politically and economically, it became part of the Soviet sphere of influence. Industrial development, after 1945, can be divided into five periods.

Period 1: The forced elaboration of the communist model of social and economic development, in parallel with the post-war reconstruction work, meant that both the ownership of the instruments of ind ustrial production and the number and sectoral distribution of industrial workers changed radically. Industrial units employing more than 10 workers were nationalized, smaller industries were made into cooperatives. In accordance with the economic policies of the one-party state, industrial development became the driving force of the whole economy (Perczel, 1996). The industrial policy of the centrally-planned economy was, actually, a reminder of the war economy, and it put an emphasis on heavy industry at the expense of other industrial branches. Heavy industry was based on exploiting and processing national resources. Thus, Hungarian industry - similarly to industries in other Eastern-bloc countries - joined a Moscow-administered economic system within the framework of Comecon (Council for Mutual Economic Assistance).

Period 2: In the 1960s, there was a change in the perception of strategies of industrial development: processing industries, using Hungarian raw materials, were 
gradually being developed. "Rural" areas, especially in the Great Plain region, were "industrialized", a process which primarily meant that low productivity plants using old technologies were "moved" to the countryside. These developments also meant that these rural areas - despite some spectacular changes - were, and still are, underdeveloped (Enyedi, 1993). This early extensive period of industrialization came to an end only in the late 1960s, when natural and social resources became depleted.

Period 3: Recognition of the necessity for intensive development, and the introduction of the "new" economy mechanism in 1968, gave a new impetus to industrial development. Economic reforms loosened the centralized management of industrial plants and this led to better integration into the international division of labour. Although the centrally planned economy was sustained, its rules had changed. These changes had a temporarily beneficial impact on the efficiency, technological level and structure of production, as well as on the quality and price of products. At the same time, it is worth noting that the majority of Hungary's industrial products were marketable within the Eastern bloc and "trade" usually meant only an "exchange of commodities" (Szijártó, 2012).

Period 4: During the 1980s, the weaknesses of the previously-described system were becoming more and more evident, and these problems (waste of energy and materials, outdated equipment and machinery, dominance of large plants, etc.) were holding the whole economy back by slowing down industrial development. Recognising these problems, the leaders of the one-party state introduced further reforms. As a result, the country's economy and financial policy were opened up to the West; indeed, even some forms of small enterprise were allowed to operate (Bod, 2014). Centrally-planned economy became redefined but the winds of reform that started to blow did not bring the desired results: foreign trade was thrown out of balance and the economy could operate only through the use of foreign loans, at the cost of immense debts. Such loans were spent on maintaining consumption levels and maintaining the liquidity of companies and cooperatives, as well as on certain developments, which were not very well received by the foreign markets. New measures were needed, which, eventually necessitated the introduction of political changes. These measures, in addition to state and cooperative ownership, also led to the birth and growth of the private sector. The change to a market economy became inevitable.

Period 5: The 1990s and the changing of the political system in Hungary opened a new chapter in the history of Hungarian industry. In 1996, Hungary became an OECD member country, then, in 2004, it joined the European Union. This situation radically changed the international position of Hungary's economy. Our paper will thoroughly examine the characteristics of this period.

\section{THE DEVELOPMENT OF HUNGARIAN INDUSTRY FROM THE CHANGING OF THE POLITICAL SYSTEM UP TO NOW}

After a change of the political system in the country happened, the entire Hungarian economy and Hungarian industry underwent a major transformation. Foreign investors became increasingly interested in Hungarian industry, a fact which is attested 
by a sudden increase in the number of multinational companies coming to Hungary (Pál \& Pál, 2009). After the changing of the political system, it was primarily German, Austrian, Swiss, British and Italian capitalists who first invested in Hungarian industry. These were followed by Dutch, French, American and Belgian capitalists (Fig. 1). In the order of rank of investors from the Far East today South Korea is the 9th, Japan the 11th, Singapore the 17 th and China is the 22 nd country.

Foreign investors came to Hungary in two waves. The first of these was the period of privatization, while the second can be characterized by the green- and brown-field investments of the 2000s (Mihályi, 2011). From 1989, about $40 \%$ of the foreign capital in Hungary was invested in the country's industry (Kiss, 2011). The processes of marketization and privatization resulted in radical changes in the spatial and structural features of Hungarian industry (Barta, 2002).

Fig. 1. Foreign direct investment by countries of origin at current prices - balance of payments statistics (BPM5) of the International Monetary Fund (IMF) (1998-2012)

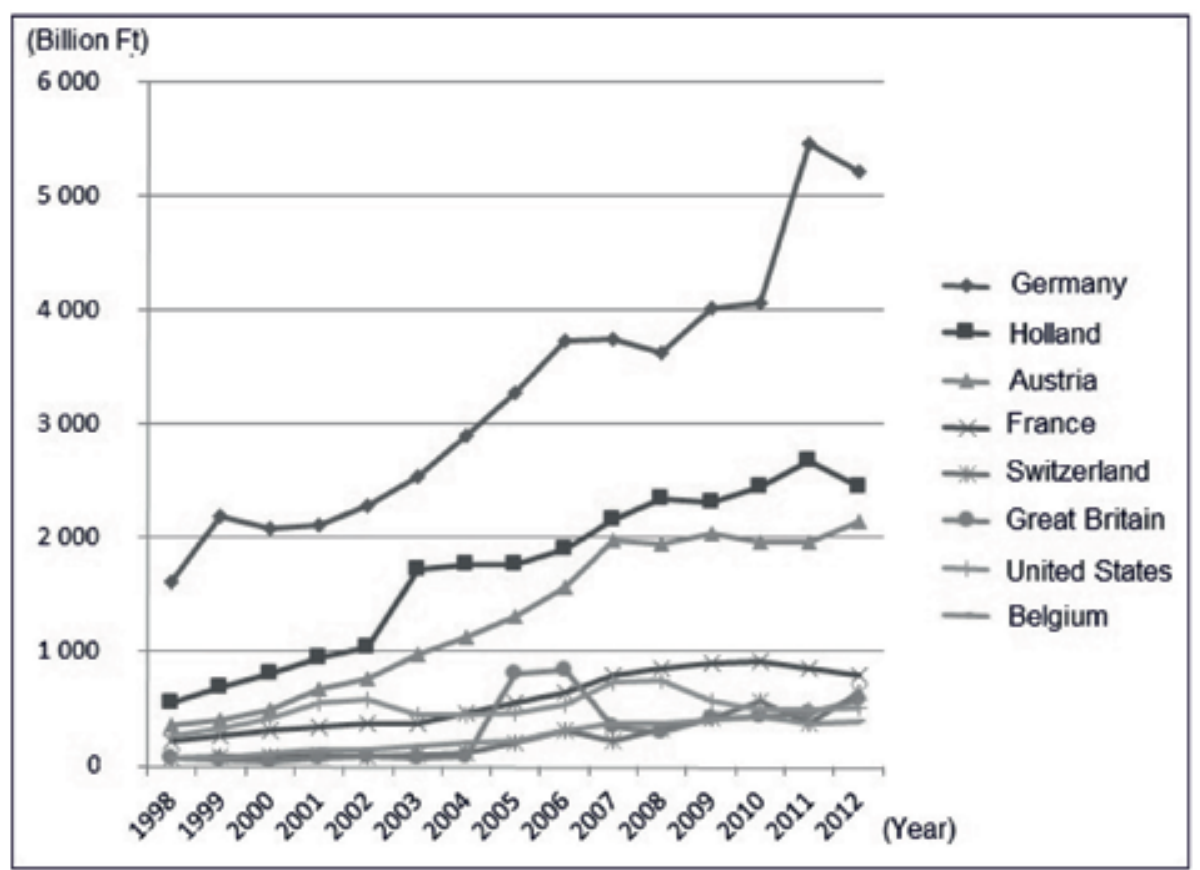

Source: the data are from Hungarian Central Statistical Office (Központi Statisztikai Hivatal). Design of the authors

The speedy privatization of the means of production had harmful effects as well. One of these was that those plants which were still in state ownership were not given the chance to compete with privately-owned enterprises. The new owners from abroad who had purchased the industrial plants at very cheap prices, were inexperienced in running businesses, and they most often closed the old industrial plants down, or, at best, they downgraded them into an insignificant foreign branch. Thus, the new owners 
could have access to new markets, cheap resources and get rid of their potential competitors (Csath, 2007) - a situation, that quickly led to a drastic fall in the country's industrial production. In the three-year period following the changing of the political system, Hungary's GDP decreased by $20 \%$; and, due to the transformational crisis, it was only by 2000 that it regained its former level.

Owing to the loss of the protected Eastern European markets, a considerable decrease in domestic consumption and competition from newly imported goods, the volume of industrial production in Hungary decreased by $1 / 3$ in a three-year period (Fig. 2). The diminishing number of industrial plants led to a process of partial de-industrialization. The negative consequences of the decline in industry were further aggravated by the harmful effects of inflation and increasing unemployment. Thus, despite the fact that due to the freedom of investments the number of industrial organizations was on the increase, the number of industrial employees decreased, by about 80,000 (Kiss, 2011). In summary, half of the former industrial capacity became redundant (Perczel, 1996).

Fig. 2. The changing volume index of industrial production in Hungary (1960-2013)

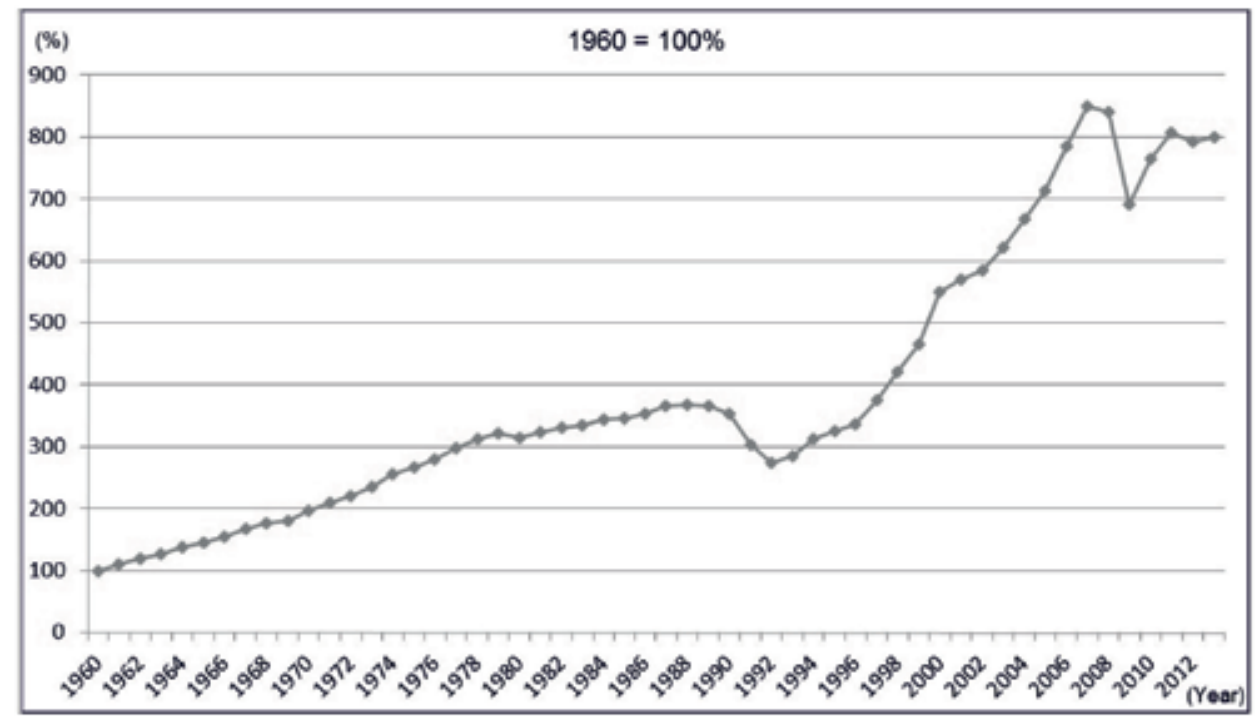

Source: The data are from Hungarian Central Statistical Office (Központi Statisztikai Hivatal). Design of the authors

Industrial production began to grow slowly again, from 1993 onwards. Then a more dynamic growth followed, from 1996 to 2007. This development was the result of favourable conditions of the world economy, as well as of government's economic policy, which attempted to attract foreign investors by offering them cheap, skilled work force and tax benefits. These measures temporarily stabilized the place and role of industry in Hungary's national economy and the foreign capital was beneficial - from the point of view of structural changes and modernization - and intensified the export of goods as well (Botos, 2010). Productivity improved significantly during this period, 
due to the making redundant of the superfluous work force. After 1996, new and upto-date management styles and techniques, as well as production technologies, were introduced, too.

On the other hand, it was a serious problem that foreign businesses were enjoying many privileges which were not given to Hungarian enterprises. As a result of this situation, the majority of industrial eneterprises and other means of production were in the hands of foreign investors; consequently, the product composition unfavourably shifted toward the production of cheap appliances - typical of dependent economic peripheries (Csath, 2007). Undoubtedly, in the two decades following the changing of the political system, foreign subsidiary companies operating in Hungary significantly contributed to the adaptation of state-of-the-art-technologies and to the modernization of the entire economy. At the same time, they operated as "modern islands" and did not cooperate with Hungarian companies and businesses. This situation strengthened the already existing duality of the structure of Hungary's economy - a feature which was familiar in other Eastern European countries, as well (Günther, 2002).

The green-field investments (assuring growth) mostly favoured export-oriented sectors manufacturing high-added-value products, such as vehicle manufacturing, electronics, and electrical engineering. In addition to state-guaranteed investment subsidies, investors were also attracted by the built-up infrastructure, the favourable geographical (logistical) location, the professional structure of human resources and the traditionally good labour relations system. These features were beneficial to the central region of Hungary in the vicinity of Budapest, and to certain other regions in Western Hungary.

Since industrial production and sales have always been influenced by the world main trends, especially in Europe's economy, is is obvious that the impact of the economic crisis following the millennium should be felt in Hungary as well. At the same time, it is a fact that from the mid-1990s to the mid-2000s there was only one country in Europe, Ireland, that was able to produce growth larger than that of Hungary (Kukely, 2004). From the changing of the political system until now, Hungary's industrial production had a peak year in 2000 , when production grew by $18 \%$; then from 2003-2007 there was an annual growth of 7-10\%. These favourable changes were due to the Széchenyi Plan, a new model of economic development, elaborated for the period 2001-2006. The Széchenyi Plan builds on a skilled workforce, innovation and capital investment (Botos, 2010).

It was in 2008 that a period of major economic recession began all over the world, which resulted in the fall of all Hungarian industrial indicators. The economic philosophy of "competing on the cheap" and its practical implications failed (Csath, 2007). The value of industrial production began to fall sharply (Fig. 3). In order to alleviate the impact of the crisis, the government elaborated short- and long-term action plans in the area of industrialization. These plans were shortly pushed into the background by the political aims of the second Orbán government, aimed at re-industrialization (New Széchenyi Plan, 2011). As the crisis subsided, the new measures resulted in improved economic atmosphere. 
Fig. 3. The changing of industrial production in Hungary at current prices (2001-2014)

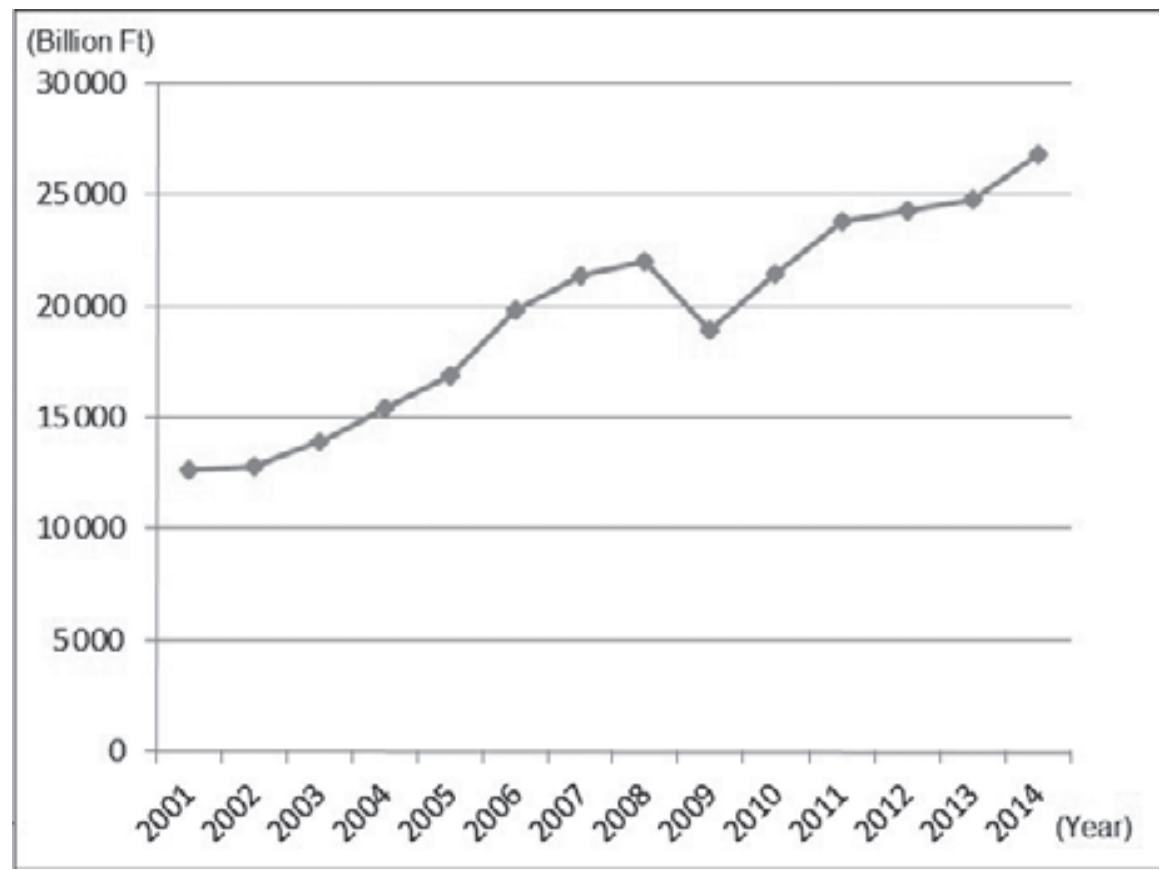

Source: The data are from Hungarian Central Statistical Office (Központi Statisztikai Hivatal). Design of the authors

\section{CONTEMPORARY DEVELOPMENTS IN INDUSTRY IN HUNGARY}

The weight of industry in Hungary's economy can be characterized by the fact that, during the last few years, it has represented about $1 / 4$ of the country's economy. The value of industrial investments (purchases of machinery and equipment, construction of buildings) reached a peak in 2010 (Fig. 4). Industrial investments today represent one third of all Hungarian investments. If financial investments are deducted from the total sum, industrial investments represent about one half of all investments.

The decrease in the number of industrial employees after the changing of the political system in Hungary seems to have come to a standstill. Proportionately, during the past 5 years, this figure was about $22 \%$, but those of the competitive sector are even more favourable (34\%) and are still on the rise. In 2013, the number of those who were employed in industry (in SME-s employing more than 5 people) was 625,000, which exceeds the figure from the previous year by $0.6 \%$. Three-quarters of all industrial employees did some kind of manual labour. Unfortunately, the so-called "structural unemployment" is not unknown in Hungary. There are examples when employers cannot find employable people for a certain job, or, when the applicants lack the necessary qualification for the job. 
Fig. 4. The share of industry from Hungary's GDP, investments, employment and number of enterprises (2005-2013)

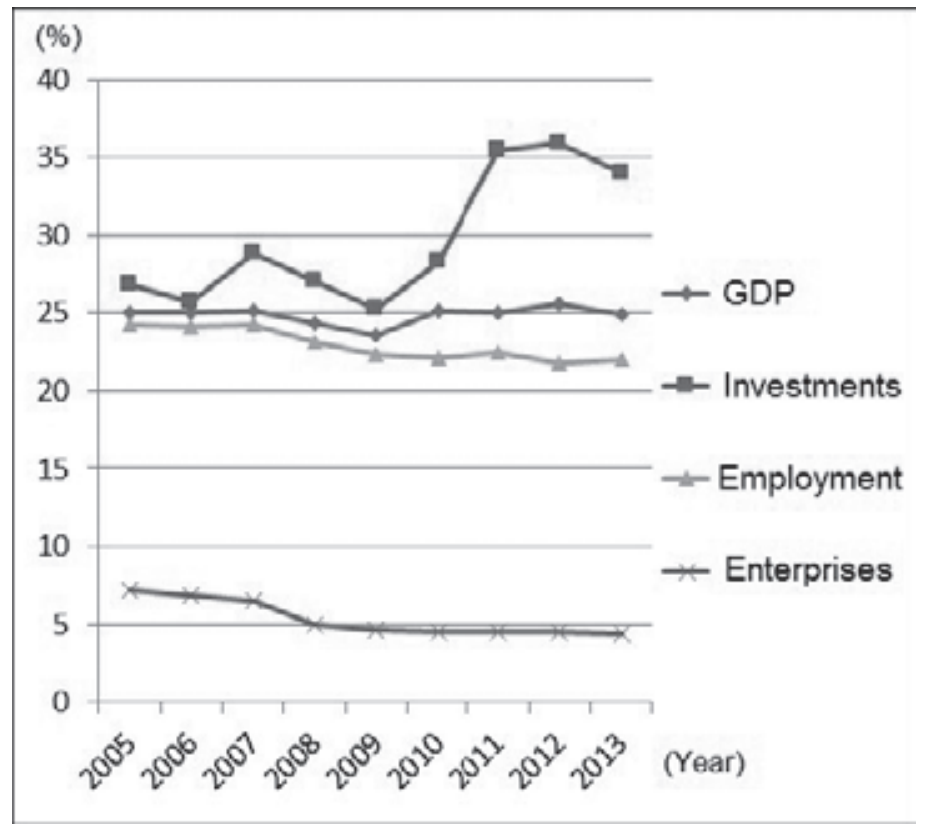

Source: The data are from Hungarian Central Statistical Office (Központi Statisztikai Hivatal). Design of the authors

Although, owing to the recession, the return from sales calculated jointly from exports and imports significantly decreased in 2009, by 2013, it approached HUF 30 billion (100 billion euros), a figure which is ten times more than that of 2000 . This rapid expansion was primarily due to the growth in exports (Fig. 5). During the last two decades - except for the recession years of 2009 and 2012) - it has always been the export sales that have represented the driving force in growth, with the processing industry playing the most important role. This fact is also indicative of the country's dependence on external economic trends (Központi Statisztikai Hivatal, 2014).

The business fever that evolved after the changing of the political system coincided with changes in the structure of industry. The number and type of new businesses (companies) soared. It was primarily the well-positioned state companies that were changed into private companies and partnerships and, in addition, the newly emerging companies concentrated in the most profitable sectors (Nemes Nagy, 1992). On the other hand, there was a parallel process, i.e. many large and unprofitable companies ceased to exist in the very same period. With the disappearance of unviable businesses the number of industrial enterprises has gone down to 74 thousand by now. More than $4 / 5$ of these is small enterprises (with fewer than 5 employees) which give less than $5 \%$ of the industrial production (Központi Statisztikai Hivatal, 2014). It means that the structure of businesses was fragmented and, at the other end of the scale there were only a few truly large enterprises (Mihályi, 2012). On the other hand industrial 
production is heavily concentrated: more than $70 \%$ of it is produced by 400 large businesses, each oh them having more than 250 employees. Another problem of the dual structure of the economy is that while the efficiency of large companies in Hungary is at a European level, the efficiency of small- and medium-sized enterprizes (SMEs) represents only $40 \%$ of the European average.

Fig. 5. Turnover from export and import industrial sales at current prices (2000-2013)

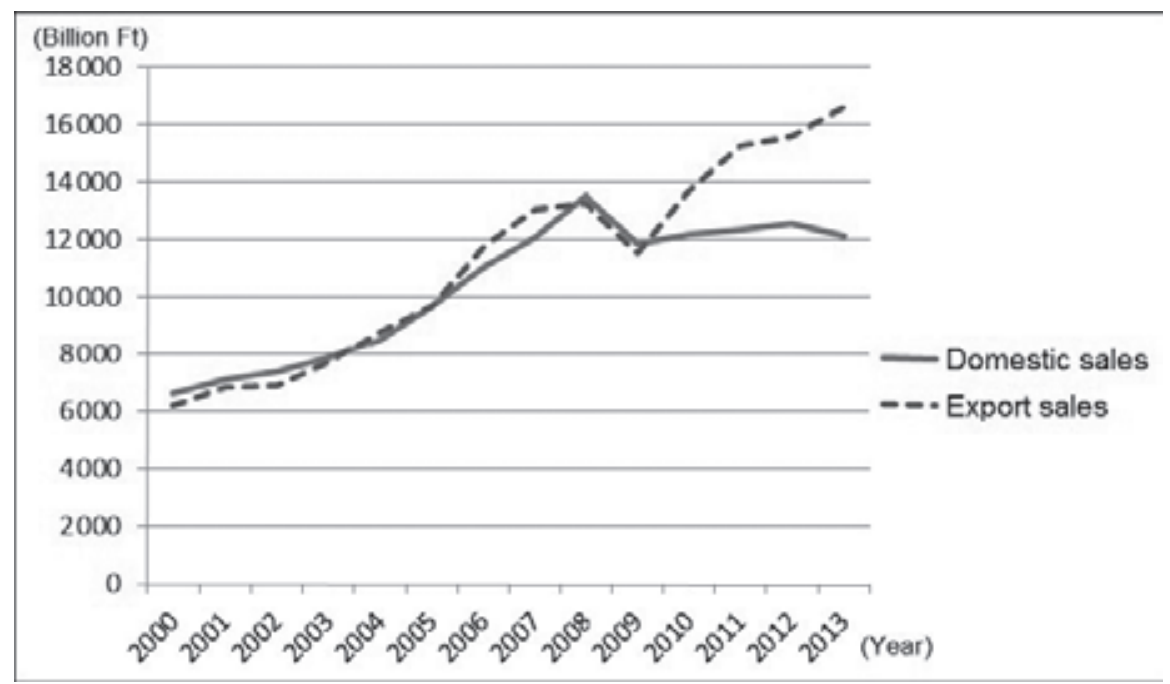

Source: The data are from Hungarian Central Statistical Office (Központi Statisztikai Hivatal). Design of the authors

The decisive proportion of industrial production in Hungary (94\%) can be linked to processing industry and, although there are some minor set-backs, it is still expanding (Tab. 1). Its production primarily depends on sales on international markets. In addition, machine industry, and especially, vehicle manufacturing, which took the leading position in 2011, have gained significance. (Központi Statisztikai Hivatal, 2014). It is one third of industrial employees that work in Hungary's machine industry.

The Hungarian automotive industry has long traditions: before the first world war ten, and between the two world wars, five models were developed and produced in Hungary, including the Marta and Magomobil. In the decades of communism, Hungary, as a member of COMECON, specialized in manufacturing utility vehicles; bus manufacture became the leading branch in vehicle production. The company "Ikarus" became the second largest bus manufacturer in Europe, after Mercedes.

After the changing of the political system - primarily due to the proximity of markets and the presence of a skilled labor force - there was an increased interest in investment opportunities in vehicle manufacturing industry in Hungary. In the early 1990s, passenger car production (Suzuki, GM-Opel, VW-Audi) was relaunched. Today, vehicle manufacturing - as part of the global vehicle manufacturing systems - is one of the most dynamically developing industrial branches: the number of companies in this area tripled during the last two years. This branch has about 1000 companies in it, producing 
approximately one fifth of Hungary's total industrial production and which, in 2013, had 80 thousand employees, the value of their production exceeding HUF 5400 billion. In 2014, the four largest car manufacturers, VW-Audi, Daimler, GM-Opel and Suzuki created more than 2,500 new jobs. The world's ten largest car manufacturers, including the previously mentioned four, have some production capacity in Hungary. In addition, half of the world's one hundred largest car industry suppliers (e.g. Continental, Bosch, Magna, Denso) are present in Hungary (Bíró, n.d.). In 2014, the domestic sales of car manufacturers increased by $60 \%$.

Tab. 1. Changes in industrial production by branches of industry from 2001 to 2013

\begin{tabular}{|c|c|c|c|c|}
\hline \multirow{2}{*}{ Year } & Mining & Processing industry & Energy industry & Total \\
\cline { 2 - 5 } & \multicolumn{4}{|c|}{ Billion Ft } \\
\hline 2001 & 67 & 11154 & 745 & 11966 \\
\hline 2002 & 64 & 11295 & 806 & 12165 \\
\hline 2003 & 65 & 12285 & 925 & 13275 \\
\hline 2004 & 74 & 13677 & 1005 & 14756 \\
\hline 2005 & 74 & 15004 & 1233 & 16185 \\
\hline 2006 & 89 & 17664 & 1479 & 20439 \\
\hline 2007 & 74 & 18886 & 1518 & 20952 \\
\hline 2008 & 104 & 19329 & 1468 & 17963 \\
\hline 2009 & 94 & 16401 & 1484 & 20462 \\
\hline 2010 & 74 & 18905 & 1529 & 22655 \\
\hline 2011 & 84 & 21042 & 1573 & 23141 \\
\hline 2012 & 99 & 21470 & 1378 & 23576 \\
\hline 2013 & 94 & 22103 & & 1896 \\
\hline
\end{tabular}

Source: The data are from Hungarian Central Statistical Office (Központi Statisztikai Hivatal)

In summary, Hungarian car manufacturing portfolio is one of the most competitive part of global industry and the presence of international companies motivates Hungarian suppliers as well. These latter enterprises may contribute to the work of the manufacturers with some definite product or other added value, and take over more and more work from the parent companies located worldwide. Although it is important to add that it is only the largest companies of solid capital that are able to work on assembly lines; lower levels of production offer good opportunities for many Hungarian SMEs, too.

The prestigious Hungarian chemical industry was involved in rubber and plastics manufacturing; today, coking, crude oil processing and the pharmaceutical industry are among Hungary's leading industries (Fig. 6). Within the group of processing industries it is the food processing industry that takes 3rd place and that can be characterized by a diminishing number of production sites, changing product structures and a forced adaptation to the growing market share of transnational companies. The textile, clothing 
and leather industry lost its first battle against inexpensive import from the Far East struggling along in a long state of crisis in the 1990s, but a slight increase can be observed from 2010 onwards.

Fig. 6. Changes in the structure of Hungarian industry by the value of industrial production from 2001 to 2014

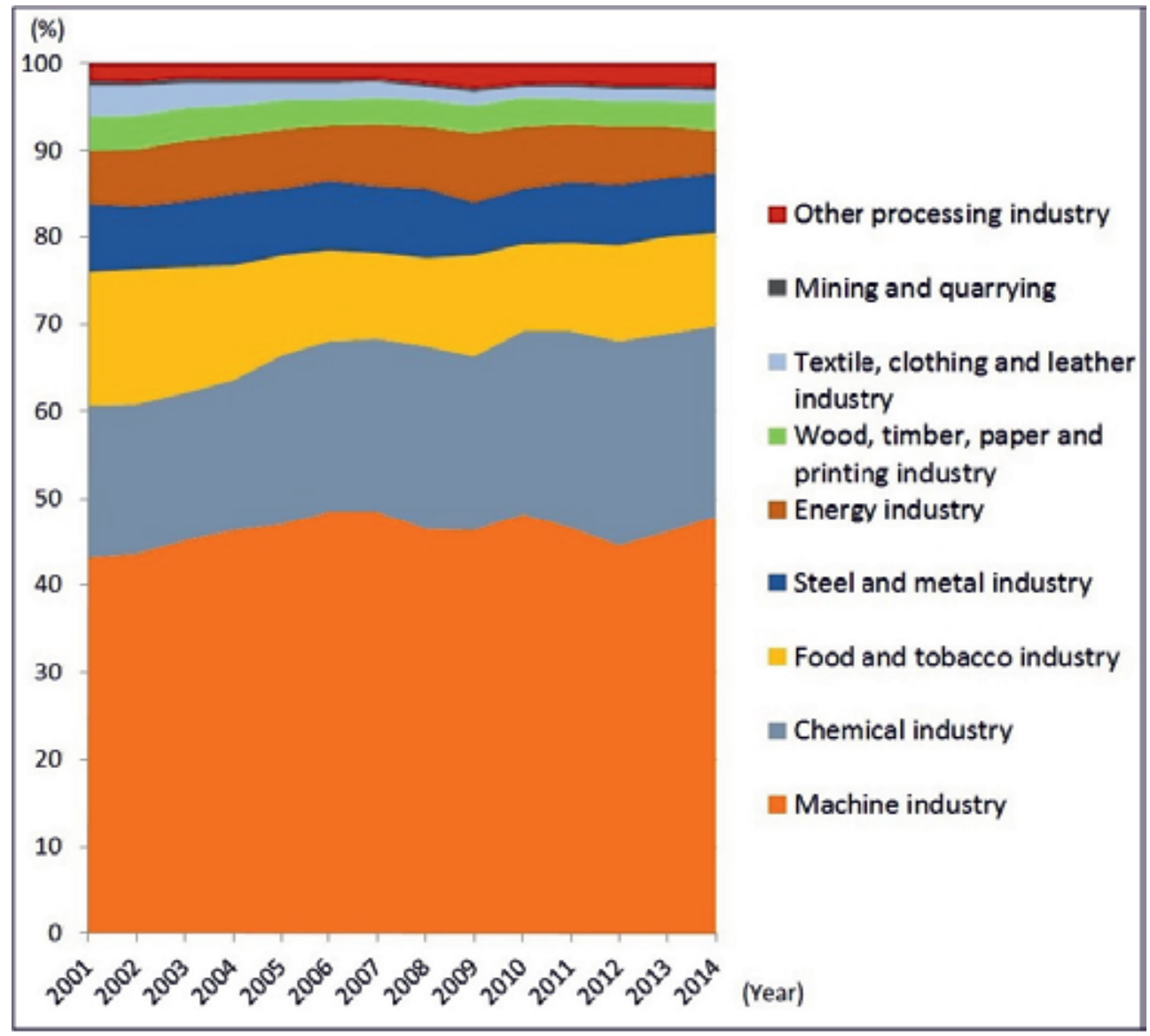

Source: The data are from Hungarian Central Statistical Office (Központi Statisztikai Hivatal). Design of the authors

Due to its geographical features in the structure of Hungarian industry, it is mining that plays the least important role $(0.4 \%)$. Several deep-exploitation coal- and oremines were closed down during the 1980s and only one metallurgical plant (Dunaújváros) remained in operation. In the area of the energy sector (electric power, gas and steam supply, air conditioning), there has been a decline (5.6\%) as well which can be explained by the diminishing production of gas-based power plants, energy efficiency due to modernization and a fall in energy consumption due to generally milder winters. 
In industrial export, as well as in production, efficiently operating large international companies have a significant share. An increasing number of Hungarian companies are related to these as suppliers and this is how they can enter the international markets. Unfortunately, at present, only few Hungarian companies can seize this opportunity. It is the vehicle manufacturing industry - which has a market share of $30 \%$ - that can offer Hungarian businesses excellent opportunities for cooperation. Sales figures in the vehicle manufacturing industry, similar to those of Central-Eastern European countries and China, exceed average growth data. In order to achieve further improvements in the areas of industry, trade and market protection, well-considered policies are needed (Botos, 2010).

More than half of foreign investment comes from those international companies which have already settled in. In 2012, 1180 billion forint sin industrial investments, $76 \%$ of gross industrial investments of HUF 1539 billion, were made by subsidiary companies, managed from abroad. This proportion was the highest (78\%) in the processing industry; this is followed by the energy sector (65\%) and mining (52\%). The largest investors are from the European Union countries.

\section{SPATIAL STRUCTURAL CHANGES AND THE INDUSTRIAL PARKS}

During the last 25 years, radical functional changes in industry influenced the geographical distribution of industry and its spatial structure. During the communist era, there were two large industrial zones in Hungary:

a) the so-called northeast-southwest industrial axis including the mountains of medium height in Central Transdanubia and Northern Hungary. In these areas mining, energy production and raw materials production were significant.

b) Budapest, and its agglomeration zone, including a broad range of processing industry and the headquarters of large state-owned companies.

The industrial decline that followed the changing of the political system primarily affected mining and metallurgy (the so-called crisis sectors), as well as several newly-established industrial centres in the capital and their subsidiary branches in larger Hungarian cities (Perczel, 1996). These developments coincided with a reduction in the number and proportion of industrial employees. The capital city and the areas nearby suffered from a recession of significant proportions. In addition to structural changes, this was due to an expansion of the service industry. Still, Budapest is the country's number one industrial centre, excelling in information technology and state-of-the-art industrial developments which are based on research and development. The majority of large companies operating in Hungary can be found in the country's central region, including in Budapest (Mihályi, 2012).

After the changing of the political system, functioning foreign capital, which was invested in the industrial sector, aimed to assist the development of industry in Hungary's central region. Due to the favourable transportation conditions and the accessibility of the capital, the role of nearby industrial parks became increasingly important. This is why foreign capital re-targeted the northern part of Hungary's Transdanubian region, and, thus, the centre of industrial production started to shift toward the west, where 
Fig. 7. The value of industrial production by counties in 2001 and 2015

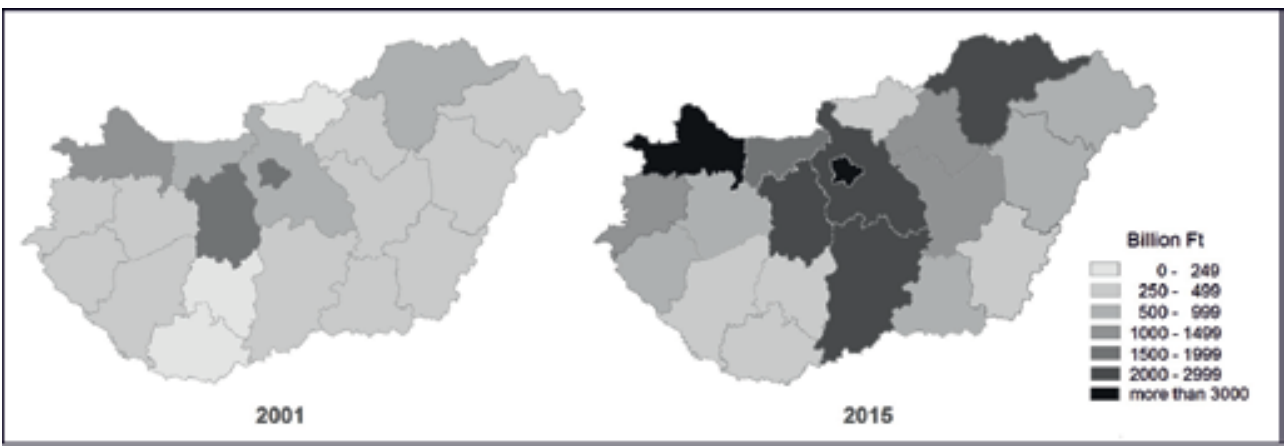

Source: The data are from Hungarian Central Statistical Office (Központi Statisztikai Hivatal). Design of the authors

the new industrial centres of Esztergom, Komárom and Szentgotthárd sprang up. These were towns where a skilled work force was available, transport conditions were excellent, infrastructure was well-developed and the German language was widely-spoken. Some of the former industrial centres in the region, including Győr, Székesfehérvár and Tatabánya, were also able to revitalize their economies. Today, this formerly-described industrial region is the home to many of the 500 most-profitable companies in Hungary, including GE, Audi, Nokia, Lear Co., Continental Teves and Alkoa-Köfém, the majority of which represent various branches of the machine industry (Kiss, 2008). The uneven spatial distribution of industry in Hungary is reflected in regional data, as well: the values of industrial production are the highest in Central and Western Hungary and in Central Transdanubia. The value of industrial production increased differentially by counties (Fig. 7).

Today it is the Győr-Moson-Sopron, Komárom-Esztergom, Fejér, Bács-Kiskun and Borsod-Abaúj-Zemplén counties that can boast the largest investments into technology and the highest rates of industrial growth. Some large transnational companies, including for example Philips, Nokia and Suzuki, opened subsidiary branches in this region, with their suppliers located in the vicinity as well (Kiss, 2011). The conditions are much less favourable in other regions, in those former centres of heavy industry which were located along the "industrial axis". Examples include the cities of Miskolc, Salgótarján and Ózd, as well as the regions of southern Transdanubia and the larger part of the Great Plain region.

After 2008, a year of recession, the number of industrial employees decreased in each region - except for southern Transdanubia. Growth was first generated in the southern Great Plain region: then this trend was detected in Central and Western Transdanubia and in the Northern Great Plain region as well. It is in the last two years that conditions have improved significantly in Central Hungary also. Only the two Great Plain regions and Western Transdanubia have reached pre-2008 levels (Fig. 8). In general, there have been some improvements, but there are still significant differences between particular regions of the country.

According to Kiss (2008), due to the re-industrialization process, the former NESW industrial axis is to be replaced by a new, contiguous industrial area comprising 
Fig. 8. The number of industrial employees by regions from 2008-2014

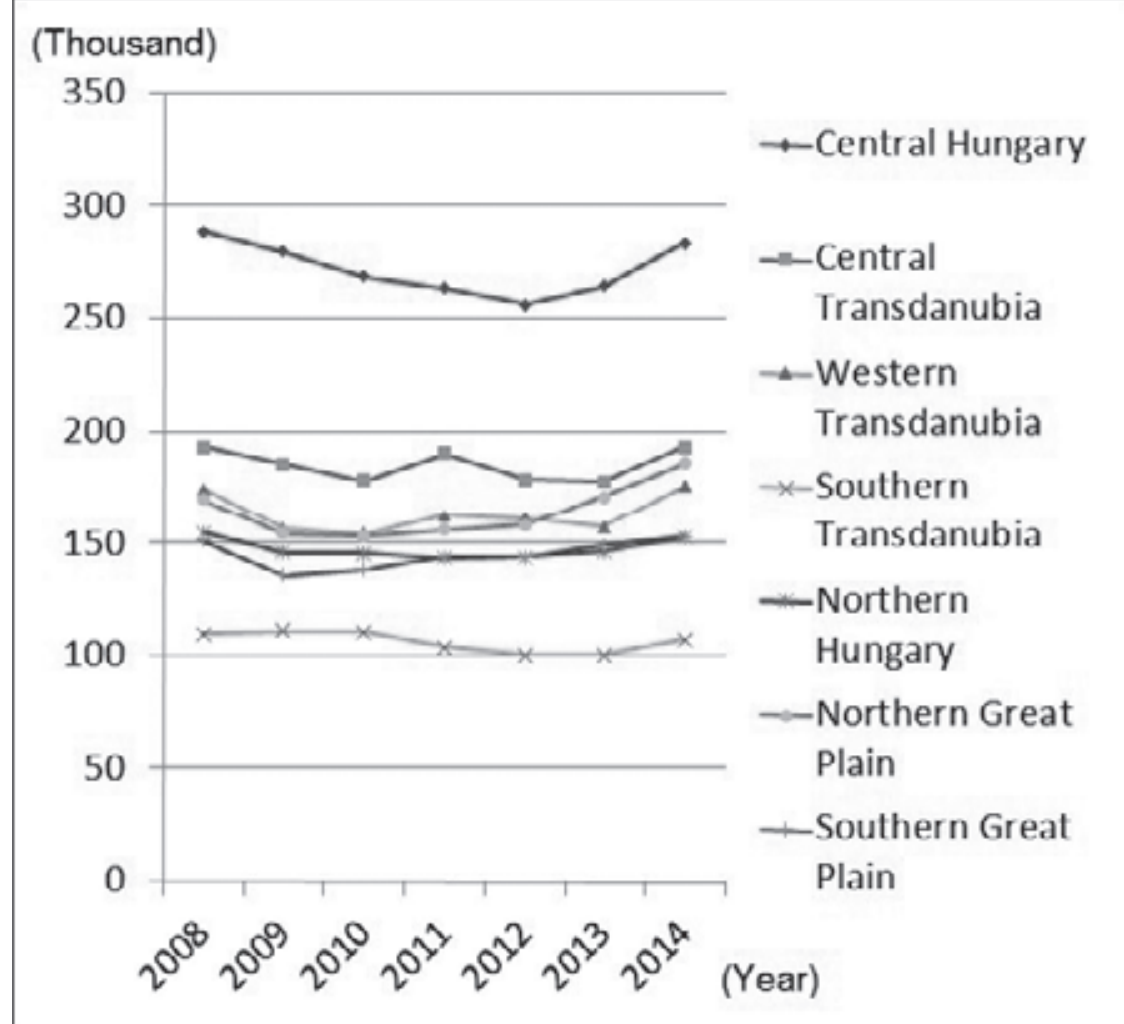

Source: The data are from Hungarian Central Statistical Office (Központi Statisztikai Hivatal). Design of the authors

Northern Transdanubia and the region of Central Hungary. Owing to its vehicle manufacturing and the industrial activities of a large number of suppliers, the new, industrially active centres of Kecskemét and its surroundings are about to join this large region (Fig. 9). As a result of this new, post-Fordist development, foreign capital has played an important role in the emergence of Hungary's newest industrial zone.

When compared with developments in Western European countries, it can be stated that the emergence of industrial parks in Hungary was belated, but they quickly became popular. In this development, a variety of factors played a role, including the creation of new jobs, the re-utilization of former industrial areas and buildings, the exploitation of agricultural lands of poor quality, border zone characteristics and access to project funds. Although it was in Győr that Central and Eastern Europe's first industrial park was opened in 1991, in Hungary industrial parks became officially recognized only in 1997. The majority of these came into being as green-field investments, but industrial parks were established in old industrial sites as well.

The emergence of industrial parks is a phenomenon typical of urbanization. Most often they come into being due to some bottom-up organizational work done by local 
Fig. 9. Changes in the structure of Hungarian industry after 1990

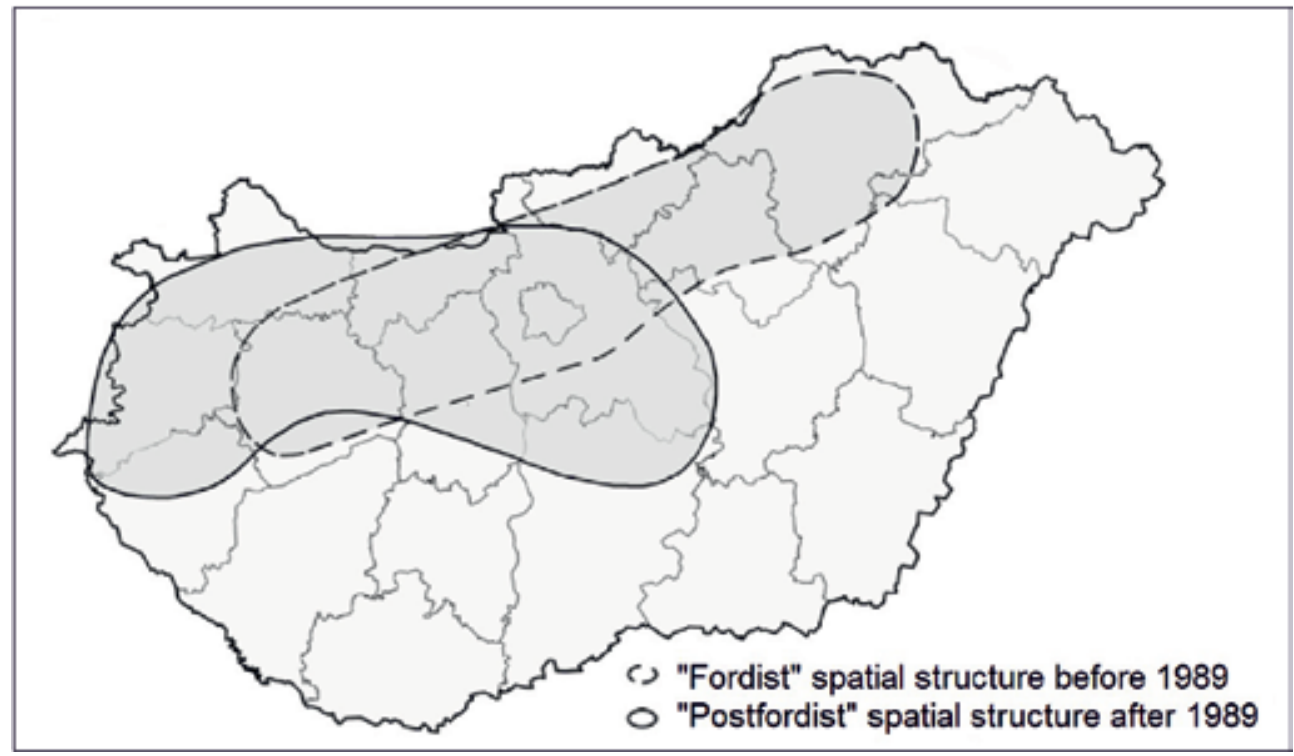

Source: Kiss, 2008: 552.

government members and businesses. From 1990 onward, there was also the possibility for them to gain access to government funds. Today, industrial parks can be found all over the country and significant amounts have been invested in them. Recently, the number of industrial parks in Hungary is about 250 giving home to about 400 businesses and employing 200,000 people. The success of industrial parks is largely dependent on local conditions, especially in the areas of transport and accessibility. At the same time, it should be noted that industrial parks in Hungary represent different stages of development. Based on figures by Éva Kiss, in 2010 the average utilization of their areas was 58\% (Kiss, 2013). They offer good opportunities for competing companies to establish cooperating clusters. About one third of clusters in Hungary are related to some industrial activity. The largest numbers of industrial parks can be found in Northern Hungary and in the Southern Great Plain region. Paradoxically, the relative evenness of their spatial distribution did not have a beneficial effect on the spatial unevenness of industrial production in Hungary.

\section{SUMMARY AND CONCLUSIONS}

Hungarian industry has long traditions. Today it is in a state of transition and similarly to other periods in its history - it is undergoing a period of change. Production should be flexible and must be in accordance with the needs of the market. Consequently, product structure and production volume change very quickly. After the failure of planned economy and of crisis management (concepts that followed the change in the political system), contemporary Hungarian industry has to cope with the challenges of an open economy in which it depends on global economic processes, the impact of 
globalization, the direction of capital flow and the possibilities for cooperation between the East and West.

The re-industrialization of today mostly takes place through investments made by international companies, i.e. it manifests itself as a partial process of global industrial transformation. However, local characteristics are also part of transfromation and structural changes simultaneously shape the spatial structure of industry. Traditional industrial regions undergo a transfromation: they have changed functions and have significantly shrunk since the changing of the political system. New industrial regions have also emerged. The process of re-industrialization was beneficial to those regions which had a favourable geographical location and which had mobile human and other resources available. Motor vehicle manufacturing has become the most dynamically developing segment of Hungarian industry; the pharmaceutical industry and IT have also gained significance considering their structure and capacity.

The future of Hungarian industry is hopeful, since several industrial players have been able to integrate into the European economic network; they have been able to keep up with the speed of development, are well-prepared for new investments which come both from Hungary and abroad and they can utilize EU funds. The major competitive advantage of Hungary is the relatively low wage level and the cheap prices, particularly in services. Flexible labor regulations, industry investment supports, improvement of the regulatory environment, as well as strategic agreements recently concluded with the industrial companies also contribute to the competitiveness of the Hungarian industry. It is also promising that the Hungarian government has revealed that its intention with the Operational Program for Economic Development and Innovation (2014-2020) was that $60 \%$ of the incoming EU funds - contrary to the $25 \%$ of the previous period (2007-2013) - would be used for economic development. This is a unique opportunity for Hungarian companies to stabilize their position in the economy of Hungary, as well as in Europe.

On the other hand, due to the size and the economic capacity of the country, the reality is that Hungarian companies most often work as suppliers for large international companies. Hungarian businesses have to be assisted with their aspirations to become productive suppliers, to expand their export capacity and to appear in the global market with innovative products. We should not forget that nowadays innovation is typical of the activities of parent companies, their subsidiaries and their suppliers as well. What is more, suppliers in total spend more money on research and development than the end-product issuer. Supported have to be those companies that excel in efficiency and innovation. In modern economy the aim of survival is far from being enough.

The so-called integrator companies which serve as links between large and smaller enterprises and which are assisted by the Hungarian Chamber of Industry and Trade, play a prominent role in the development of business culture and the promotion of market possibilities in Hungary. These companies may help SMEs with mentoring and counselling activities, incubation, network building and modern business services. SMEs are now able to serve large industrial players because they are inventive, creative and efficient, and they concentrate on quality production in spite of the fact that, sometimes, it is difficult for large international companies to choose the best suppliers. 
Those companies which are not only part of a domestic supplier chain, but which also function as direct suppliers of a large parent company, can enter the European market without any difficulty, since expectations and the conditions are the same.

Concerning the spatial structure of industry, it is important to note that industrial decentralization, the support of businesses located outside of Budapest and assistance also needs to be given to players in the national and local markets. As far as human resources are concerned, it is very important to strengthen secondary-level and higher-level vocational education in the area of engineering. When compared with similar data from the more developed countries of Western Europe, the proportion of those who participate in dual-type vocational training is, unfortunately, low in Hungary. Regional universities must strategically liaise with the production sphere in the areas of training options, innovation and internationally-acknowledged research and development. The sustainability of industrial success, on a more permanent basis, can only be achieved if there is a continuous and meaningful dialogue between the government, higher education and businesses themselves.

\section{References}

Barta, Gy. (2002). A magyar ipar területi folyamatai 1945-2000. Budapest-Pécs: Dialóg-Campus Kiadó.

Barta, Gy., Czirfusz, M., Kukely, Gy. (2008). Újraiparosodás a nagyvilágban és Magyarországon. Tér és Társadalom, 22(4), 1-20.

Bíró, Cs. (2015, April 30). Top 100 autóipari beszállító - full list. Retrieved from: http://www. autopro.hu/beszallitok/Top-100-autoipari-beszallito-teljes-lista/14390/

Bod, P. Á. (2014). Nem szokványos gazdaságpolitikák. Budapest: Akadémiai Kiadó.

Bora, Gy. (1986). Ipar. In T. Bernát (ed.). Magyarország gazdaságföldrajza. Budapest: Kossuth Könyvkiadó, 79-156.

Botos, B. (2010). Az iparpolitika metamorfózisa. Budapest: L'Harmattan Kiadó.

Csath, M. (2007). The Competitiveness of Economies: the Case of Hungary. In J. Jabłoński (ed.). Foundations of Control and Management Sciences. Poznan: Poznan University of Technology, 17-32.

Enyedi, Gy. (1993). Az Alföld fejlődésének perspektívái. In J. Timár (ed.). Az „alföldi út” kérdőjelei. Békéscsaba: MTA RKK ATI Békéscsabai Osztály, 13-16.

Gulyás, L. (2010). Trianon hatása a Kárpát-medence régióinak fejlődésére. Közép-Európai Közlemények, 3(4), 140-147.

Günther, J. (2002). FDI as a multiplier of modern technology in Hungarian industry. Intereconomics. 37(5), 263-269.

Győri, F. (2011). Tehetségföldrajz: Magyarországi vizsgálatok. Szeged: Egyesület Közép-Európa Kutatására.

Hajdú, Z. (1996). Törtneti földrajzi folyamatok. In Gy. Perczel (ed.). Magyarország társadalmigazdasági földrajza. Budapest: ELTE Eötvös Kiadó, 64-146.

Kiss, É. (2008). A magyar ipar térbeli szerkezetének átrendeződése 1989 után, II. Területi Statisztika, 48(5), 544-553.

Kiss, É. (2009). Industry. In K. Kocsis \& F. Schweitzer (eds.). Hungary in Maps. Budapest: Hungarian Academy of Sciences Geographical Research Institute, 153-163.

Kiss, É. (2011). Ipar. In K. Kocsis \& F. Schweitzer (eds.). Magyarország térképekben. Budapest: MTA Földrajztudományi Kutatóintézet, 176-188. 
Kiss, É. (2013). Sokszínű ipari parkállomány. In. É. Kiss (ed.). A hazai ipari parkok különböző dimenzióban. Budapest-Pécs: Dialóg Campus, 11-39.

Központi Statisztikai Hivatal (2014). Jelentés az ipar 2013. évi teljesítményéről. Budapest: Központi Statisztikai Hivatal. Retrieved from: http://www.ksh.hu/docs/hun/xftp/idosza$\mathrm{ki} /$ jelipar/jelipar13.pdf

Központi Statisztikai Hivatal (2016, March 24) Ipar. Budapest: Központi Statisztikai Hivatal. Retrieved from: https://www.ksh.hu/ipar_t

Kukely, Gy. (2004). A területi és ágazati struktúra átalakulása a magyar ipar húzóágazatában, a gépiparban. Földrajzi Értesítő, 53(1-2), 93-100.

Mihályi, P. (2011). A magyar privatizáció enciklopédiája. Budapest: Pannon Egyetemi Kiadó MTA Közgazdaságtudományi Intézet.

Mihályi, P. (2012). The Causes of Slow Growth in Hungary during the Post-Communist Transformation Period. Budapest: Institute of Economics, Research Centre for Economic and Regional Studies, Hungarian Academy of Sciences.

Nemes Nagy, J. (1992). Margójegyzetek a regionális politikához. Tér és Társadalom, 6(1-2), 6976.

Pál, Á. \& Pál, V. (2009). Magyarország ipari térszerkezetének változása, különös tekintettel az Alföldre. In Sz. Tóth (ed.). Tudományos és müvészeti mühelymunkák. Szeged: SZTE JGY Kiadó, 321-328.

Perczel, Gy. (1996). Ipar. In G. Perczel (Ed). Magyarország társadalmi-gazdasági földrajza. Budapest: ELTE Eötvös Kiadó, 284-370.

Probáld, F. (2011). A gazdaság általános jellemzői. In K. Kocsis \& F. Schweitzer (eds.). Magyarország térképekben. Budapest: MTA Földrajztudományi Kutatóintézet, 139-147.

Szijártó, N. (2012). Hogyan lett az iparpolitikából vállalkozáspolitika? Magyar alkalmazkodás az Európai Unió struktúrapolitikájához (ipar- és vállalkozáspolitikájához) - tanulságok. Közgazdaság: tudományos füzetek, 3(4), 33-49.

Ágnes Pál, dr habil./CSc, College Professor, University of Szeged, "Juhász Gyula" Faculty of Education. She acquired degrees in biology and geography from the "József Attila" University of Szeged, Hungary. She wrote her doctoral thesis (1969) in the area of regional industrial geography. Having been a research fellow of the Geographical Research Institute of the Hungarian Academy of Sciences from 1976-79, she acquired a CSc degree in 1980. She has been teaching courses in general and regional physical and human geography at the Department of Geography of the University of Szeged, Faculty of Education. Chair of the Department of Geography from 1996-2006. She has been working extensively in the area of regional, industrial and settlement geography and has been carrying out in-depth research into the social and economic characteristics of border zones and the Southern Great Plain region of Hungary. In 2004 she chose a topic from this area of studies for habilitation. She has published over 100 works, textbooks and research papers, and has participated in a variety of national and international conferences.

\section{Address:}

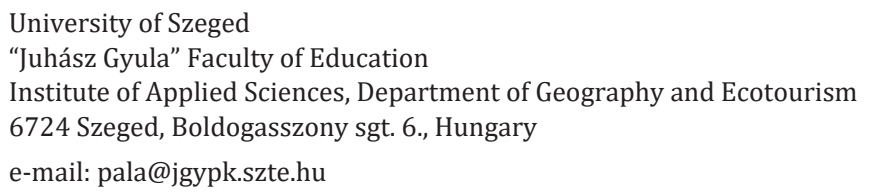

Ferenc Győri, dr/Ph.D., Associate Professor, University of Szeged, "Juhász Gyula” Faculty of Education. He graduated in geography and physical education from the University of Szeged and the "Juhász Gyula" Teacher Training College, Szeged, Hungary. He wrote Ph.D. thesis (2010) in the area of Earth science at University of Pécs. He worked as a teacher in public education, a lecturer in higher education and a scientific contributor at Hungarian Academy of Sciences, Centre for Economic and Regional Studies, Great Plain Research 
Department, Békéscsaba. He has been working broadly in the area of social, economic and cultural geography. He has been working as a thesis topic supervisor at the Doctoral School of Earth Sciences, University of Szeged. He has been teaching courses in sport tourism and recreation at the Institute of P.E. and Sport Sciences. Chair of the Institute of P. E. and Sport Sciences (2016) and the Department of Recreation and Sport Health (2012). He has published over 90 research papers and textbooks and participated in a variety of national and international conferences.

\section{Address:}

University of Szeged

"Juhász Gyula" Faculty of Education

Institute of Physical Education and Sport Sciences

6725 Szeged, Hattyas u. 10., Hungary

e-mail: gyori@jgypk.szte.hu 